\title{
RESEARCH PRIORITIES IN BANGLADESH: ANALYSIS OF CROP PRODUCTION TRENDS
}

\author{
P. C. Golder ${ }^{* 1}$, R. K. Sastry and K. Srinivas \\ National Academy of Agricultural Research Management (NAARM) \\ ICAR, Rajendranagar, Hyderabad, India
}

\begin{abstract}
Agriculture in Bangladesh is at a stage where there is a need for research priority setting. Given the physical, financial and human resource base, there is a need for proper allocation of these resources for higher and sustainable growth in production and productivity. On the other hand, resource allocation is needed to be distributed based on the commodity and regional importance. The study generates indices of research priorities for the crop sector of Bangladesh in terms of commodities and regions keeping in view the national developmental goals. Growth rates were calculated and compared share of different sectors, commodities were used to determine the priorities which is basically initial base of the congruence analysis method. Literature survey was carried out to understand the priorities at different point of times given the grand realities based on the secondary data. Division wise share analysis was done to determine the regional priority. The study concludes and emphasizes the need for (a) the increased allocation in agricultural research (b) strengthening of rice research activities (c) proportional allocation of research budget for pulses, oilseeds, cash crops, fruits and vegetables, (d) reduction of improper trade balance in export-import, and (e) regional importance for research resource allocation.
\end{abstract}

Key words: Trend in crops, research priorities, resource allocation, Bangladesh

\section{INTRODUCTION}

Bangladesh is agriculture based country having a population of about 142 million (BBS, 2010). About $84 \%$ of the total population live in the rural areas and are directly or indirectly engaged in a wide range of agricultural production. Agriculture is the single largest producing sector of economy since it comprises about $20.6 \%$ of

\footnotetext{
*Corresponding author email: pcgolder59@yahoo.mail

${ }^{1}$ Bangladesh Agricultural Research Council, Farmgate, Dhaka
}

Received: 04.10.2012 
P.C. Golder et al.

the country's GDP and employing around $48.1 \%$ of the total labour force during the year 2010 ( Table 1). Rice, jute, sugarcane, potato, pulses, wheat, tea and tobacco are the principal crops. The crop sub-sector dominates the agriculture sector contributing about 56\% of total agricultural GDP. Fisheries, livestock and forestry sub-sectors are $22 \%, 13 \%$ and $9 \%$ respectively. Bangladesh is the largest producer of world's best jute. Rice being the staple food, its production is of major importance. Rice production was found to increase from 23.1 million tonnes in 1999-00 to 27.6 million tonnes in 2008-09 fiscal year. Crop diversification program, credit, extension and research, and input distribution policies like National

Table 1: Sectoral contribution of Bangladesh Economy for the year 2010.

\begin{tabular}{lccc}
\hline Sector & GDP share (\%) & Employment (\%) \\
\hline Agriculture & 20.6 & 48.1 \\
Industry & 29.7 & 14.6 \\
Services & 49.7 & 37.3 \\
\hline
\end{tabular}

Source: BBS, 2010

Agriculture Policy, National Food Policy, Agricultural Policy Brief, Agricultural Sector Review, Millennium Development Goal pursued by the government is yielding positive results. The country is now on the threshold of attaining self-sufficiency in food grain production.

In recent years, priority setting has established itself as an important tool in the management of limited research resources. It aims to improve strategic planning and accomplish efficient allocation of scarce research resources to improve research efficiency within the framework of national policy goals (Contant, 2001). Priority setting helps (i) review existing resource allocation, (ii) update research agenda, (iii) make resource allocations more transparent and unambiguous, and (iv) strengthen credibility of the institution in soliciting support for research.

National Agricultural Research System (NARS) is the collegial body responsible for the entire range of agricultural research in Bangladesh. It is composed of Bangladesh Agricultural Research Council (BARC) and ten national agricultural research institutes. The BARC, being the apex organization of the NARS, is responsible for strengthening the national agricultural research capability through research priority setting, planning and coordination of research, resource allocation, human resource development, monitoring and evaluation (M\&E) and impact assessment (IA). In pursuit of its mandate, BARC formulates strategic plans and conducts regular sectoral studies, coordinates the formulation of master plans by the Agricultural Research Institutes, and provides policy advices and recommendations related to agricultural Research \& Development (R\&D). 
There are two major approaches in priority setting procedures: top-down and bottom-up. Officials dominate the top-down approach and experts oriented towards achieving government goals and based on technical information provided by the research leaders and scientists. In some cases, 'top down' approach is followed in research priority setting with little or no consultation at farm level and without determining existing constraints. So, there remains a big gap between what is known and what can be done, and what is actually practiced by farmers. In case of the bottom-up approach basically farmers together with scientists is involved in the priority setting of problems and solutions. Farmers' needs, knowledge and priorities are solicited to formulate research agenda and identify research priorities. Priority setting approaches are found to be varied in different Consultative Group for International Agricultural Research (CGIAR) Centres. Generally, combining bottomup demand driven approaches with top-down supply driven approaches are recommended for priority setting in agricultural research.

Recently, Bangladesh Agricultural Research Council (BARC) has done a priority setting study by using a hybrid approach. Several group meetings were held to review the research priorities on sub-sector wise at ARI and University level. All Extension agencies e.g., Department of Agricultural Extension (DAE), Department of Fisheries (DoF), and Directorate of Livestock Services (DLS) and also Hortex Foundation were requested to provide information on identified field level problems. Four regional workshops provided valuable inputs on regional issues where all stakeholders including research, extension, educational institutes, private organizations, non-government organizations and representatives from farmers were participated. All these were taken into account in setting research priorities. Synthesis and finalization was done at a national workshop (Hussain and Iqbal, 2011).

The objectives of the present study is to see the production trends of different crops and estimate their share in Bangladesh which would serve as a platform to NARS decision makers for setting priorities in efficient way.

\section{METHODOLOGY}

The study was carried out as post-doctoral research programme at the National Academy of Agricultural Research Management (NAARM), the constituent institution of Indian Council of Agricultural Research (ICAR) located at Hyderabad, India during the period from July 2011 to January 2012. The choice of method depends on the objectives of research, level of priority assessment (national, institutional or programme) and its simplicity in application, data requirement and capacity to allow participation of stakeholders in priority assessment exercise.

The selection of the model is also guided by the level of priority setting (macro or micro), availability of data, analytical skills and resources. It is reported that different international agricultural research organizations adopt different methods in setting priorities in agriculture. The commonly used methods are congruence method, 
P.C. Golder et al.

checklist method, economic surplus model/benefit-cost analysis method, mathematical programming model, econometric model etc. Out of different methods, this study followed congruence method. Due to lack of data on sufficient variables like equity, sustainability, poverty etc only initial baseline (IBL) was worked out.

Growth rates were calculated by following the formula, = (logest (series)1)*100 in MS Excel and compared share of different sectors, commodities were used to determine the priorities which is basically initial base of the congruence analysis method. Literature survey was carried to understand the priorities at different point of times given the grand realities based on the secondary data. Division wise share analysis was done to determine the regional priority

Many types of data and other information are used for the priority setting study. These include policy papers, published data on agricultural statistics (national and global) comprising growth rate of area, production and yield of different crops, land use pattern, gross domestic product, exports and imports, price of the commodities and information taken from agricultural economists.

\section{RESULTS AND DISCUSSION}

\section{Commodity Perspective}

Out of total geographical land in Bangladesh (14.8 million hectares) area under forest accounts $17.5 \%$ of the total land area (Table 2). As per the international standards the area under forest should be about a third of the total land area (Krishiworld, 2011). Some of the areas in Bangladesh which are not available for cultivation (about 24.2\%) may be brought under forest through afforestation to balance ecosystem. Net area sown covers about $53.5 \%$ of the total land area which is about $46 \%$ in India and 21\% in Pakistan. Due to limited scope for increasing the net area sown, the areas sown more than once may be increased by using the short duration high yielding varieties with suitable cropping patterns. This will lead to more intensive cropping system with higher production status of Bangladesh agriculture. The availability of land per head in Bangladesh comes to only 0.11 hectare as compared with the availability of 59 hectares in Australia, 45.07 hectares in Canada, 4.48 hectares in the USA, 2.33 hectares in Burma, 1.21 hectares in Pakistan, 0.58 hectare in India, 0.43 hectare in the UK and 0.35 hectare in Japan (Krishiworld, 2011). This again emphasizes that with the low per capita availability of land, Bangladesh need to do well in agriculture sector to feed its ever-growing population. For this there is an urgent need to increase the cropping intensity and productivity thereby increasing the production.

Major problem in agriculture is the shrinking agricultural cropland due to increased demand for housing, industrialization and infrastructure development. Therefore, the area under all the crops and fruits and vegetables are shrinking, it is evident in table (3 and 4). The area under cereal crops is found in decreasing trend ($0.10 \%$ ) but the production (4.39\%) and productivity (5.55\%) are in increasing trend. 
This shows that there is a vertical improvement in the cereal production where the yield component played a crucial role in increasing the crop production, which is again an utmost important factor for the nation to feed its people.

Table 2: Land Use Patterns of Bangladesh (2008-09)

\begin{tabular}{l|c}
\hline ??? & \% of total area \\
\hline Area under Forest & 17.5 \\
Cultivated Area & 56.7 \\
Not available for Cultivation & 24.2 \\
Culturable Waste & 1.6 \\
Current Fallow & 3.2 \\
Single Cropped Area & 18.5 \\
Double Cropped Area & 26.4 \\
Triple Cropped Area & 8.6 \\
Net Area Sown & 53.5 \\
Total area & 100.00 \\
\hline
\end{tabular}

Source: BBS, 2010

Among the cereals, rice followed the same trend (Table 3). In Bangladesh, rice is grown throughout the year on high to deeply flooded low land in three seasons, namely, aus season (March-July), aman season (July-December), and boro season (January-June) with overlapping or short turnover periods (Dey and Norton, 1992). Among the different growing seasons, the area and production of aus and aman are found decreasing in growth rate while a very slightly positive change is observed in case of boro rice during the period from 1999-00 to 2008-09. The decrease in area and production of aus and aman rice could be attributed to the low productivity of these rice due to unfavourable and unpredictable climate, and to lack of suitable varieties for upland and deepwater rice ecosystems. Thus, with the development of irrigation facilities, farmers are loosing interest in growing low yielding aus rice and relatively shallow flooded deepwater aman rice releasing this extra land for more productive boro rice. The production of boro rice is increasing mainly due to the expansion of irrigation facilities and increase in area along with the use of high yielding varieties. All the above problems are likely to threaten the sustainability of rice production in Bangladesh unless alternative ways are found to overcome the current problems facing rice in the country. However, the total rice production has an incremental growth rate (1.35\%) and that's why rice is now in surplus in production. This increase in rice production has been possible owing largely to the adoption of modern rice varieties on around $73 \%$ of the cultivated rice land which contributes to about $85 \%$ of the country's total rice production. The area and production of wheat 
have again a negative growth rate along with its productivity (Table 4). It is reported that many wheat farmers are now shifting to boro rice because of stable and higher yield, high return and for food security (Hussain and Iqbal, 2011). As a result wheat cultivation is reducing gradually. On the other hand, area and production of maize with its productivity are found rapid growing due to its utility as feed to poultry, fish and animals as well as consumption to some extent by people mixing with wheat flour in Bangladesh. Its green parts are also used as fodder for cattle and dried parts as fuel which is becoming a scarce commodity in Bangladesh. Efforts may be taken to expand its cultivation in southern belt; greater Sylhet region etc. where lands remain fallow after harvest of aman rice.

Table 3: Annual Growth Rate (\%) of area and production of rice (1999-00 to 2008-09)

\begin{tabular}{l|c|c|c|c|c|c|c|c}
\hline & \multicolumn{2}{|c|}{ Aus } & \multicolumn{2}{c|}{ Aman } & \multicolumn{2}{c|}{ Boro } & \multicolumn{2}{c}{ Total } \\
\cline { 2 - 9 } & Area & Prod. & Area & Prod. & Area & Prod. & Area & Prod. \\
\hline Local & -10.84 & -9.72 & -6.38 & -7.89 & -6.15 & -5.60 & -7.23 & -8.36 \\
HYV & 3.55 & 4.52 & 2.92 & 2.98 & 1.10 & 3.36 & 2.06 & 3.30 \\
Total & -4.29 & -1.29 & -0.19 & -0.38 & 0.77 & 3.14 & -0.77 & 1.35 \\
\hline
\end{tabular}

Table 4: Annual growth rate (\%) of area, production and productivity of some major cereal and cash crops (1999-00 to 2008-09)

\begin{tabular}{|c|c|c|c|}
\hline Crop & Area & Production & Productivity \\
\hline Cereals & -0.10 & 4.39 & 5.55 \\
\hline Rice & -0.77 & 1.35 & 2.15 \\
\hline Wheat & -9.20 & -10.70 & -1.60 \\
\hline Maize & 29.38 & 81.90 & 40.60 \\
\hline Cash crops & -1.70 & -1.57 & 0.10 \\
\hline Sugarcane & -3.38 & -3.49 & -0.11 \\
\hline Jute & -0.50 & 1.00 & 1.51 \\
\hline Cotton & -22.24 & -12.42 & 12.64 \\
\hline Tobacco & -0.45 & 1.46 & 1.92 \\
\hline Tea & 1.16 & 2.35 & 1.18 \\
\hline
\end{tabular}




\begin{tabular}{|c|c|c|c|}
\hline Pulses & -9.17 & -8.01 & 1.27 \\
\hline Gram & -7.12 & -5.99 & 1.21 \\
\hline Lentil & -8.54 & -6.25 & 2.50 \\
\hline Mung & -11.3 & -8.45 & 3.23 \\
\hline Oilseeds & -4.83 & 5.76 & 8.24 \\
\hline Rape \& Mustard & -5.19 & -2.28 & 3.07 \\
\hline Groundnut & 0.13 & 1.43 & 1.29 \\
\hline Fruits & -3.88 & 13.55 & 18.15 \\
\hline Mango & -7.83 & 22.00 & 32.37 \\
\hline Banana & 3.60 & 5.88 & 2.19 \\
\hline Jackfruit & -14.75 & 21.01 & 4.17 \\
\hline Pineapple & 1.97 & 6.23 & 18.67 \\
\hline Vegetables & -3.56 & 2.14 & 5.91 \\
\hline Brinjal (Rabi) & -5.33 & -3.10 & 2.25 \\
\hline Cabbage & 4.60 & 8.30 & 3.53 \\
\hline Cauliflower & 5.23 & 9.43 & 3.98 \\
\hline Tomato & 3.86 & 5.21 & 1.30 \\
\hline Potato & 6.49 & 9.57 & 2.89 \\
\hline Spices & 0.73 & 18.11 & 17.31 \\
\hline Onion & 19.50 & 30.15 & 8.91 \\
\hline Garlic & 14.04 & 21.01 & 6.11 \\
\hline Chilli & -7.09 & -1.44 & 6.08 \\
\hline
\end{tabular}

There is a negative or slow growth rate in respect of area and production of cash crops (Table 4). The area and production of sugarcane is declining because it is an annual crop and can not compete with other crops. Although production technologies are available but farmers do not follow them properly as a result their yields are low and uneconomic as compared to other competitive crops. From the statistics of the last ten years, it is observed that the area under jute is continuously declining but the production and productivity has slowly increasing trend. It may be mentioned here that many jute mills have been closed by the government due to 
continuous loss and huge debts. On the other hand, due to the introduction of polypropylene, the people are using polypropylene instead of jute products. For these reasons, the demand of jute has been reduced. Instead, instability of the international market price, the farmers are shifting their jute lands to other profitable crops. The increased production and productivity might be mainly due to use of high yielding varieties with proper management. The area and production of cotton are also found declining very rapidly although its productivity is in incremental trend. The main reasons of reduction in area might be due to the long duration of the crop which can not be fixed in the existing cropping pattern and price fluctuation of cotton on the international market in the recent years. Besides this, the government policy laid more importance on food grain production, crop diversification and forest tree plantation in the cultivable land have reduced the land for cotton cultivation. However, the increased productivity of cotton might be due to modern agrotechniques (eg. improved varieties, fertilizer and pest management, irrigation etc.). Tea is an important cash crop in Bangladesh. It is one the largest agro-based industries in the country. Roughly two thirds of the tea production is consumed at home, while the rest one third is exported from which Bangladesh earns a substantial amount of foreign exchange. The area, production and productivity of tea are found increasing with slow rate. It is realized that the areas like mutation, polyploidy, tissue culture and genetic engineering are needed to be addressed to increase the productivity of tea in Bangladesh.

The area and production under pulse crops are found declining very fast ($9.17 \%$ and $-8.01 \%$ respectively) although their productivity have slow incremental growth rate $(1.27 \%)$ (Table 4$)$. The decreasing trend of area of pulses are mainly due to (i) expansion of irrigation facilities and more profitable crops are available in place of pulses in the cropping pattern, (ii) high infestation of diseases and pests compared to other crops, (iii) instability of yield due to micro-climatic fluctuations, (iv) negative response to pulses to high inputs etc. The incremental growth of productivity might be attributed to slow growth rate of production compared to area as well as the use of high yielding varieties with proper management.

The area under oilseeds is found decreasing but the production and productivity are in increasing trend due to use of high yielding varieties (Table 4). Although about seven oilseed crops are grown in the country but mustard alone occupies about $70 \%$ of the oilseed land followed by sesame, groundnut, linseed, soybean, sunflower and niger. Though these crops are grown in a small area of land are contributing much to increase the productivity. Groundnut and soybean are not currently being used for oil extraction. It is assumed that irrigated rice production during the rabi season displaced oilseed, pulse and spice crops that led to serious shortage of these commodities and dependence on imports.

Fruits are in general rich in vitamins and minerals, and are essential items of a balanced diet. A daily consumption of $85 \mathrm{~g}$ of fruits is recommended for a person 
(Bhuyan and Hossain, 2009). But the availability per head per day of locally produced fruits in 2008-09, was only 25g (BBS, 2010). The area under fruits is found decreasing but its production and productivity are in increasing trend (Table 4). Development of improved varieties and management are the gateway of this achievement. However, there is more scope to increase the production and productivity of fruits through year round production, improvisation of underutilized fruits, supply of quality planting material, reducing post-harvest losses etc.

The growth rate of area under vegetables is also found decreasing but the production and productivity are in increasing trend (Table 4). It is observed that the production of this crop is 3.15 million tonnes in 2008-09 which is less compared to the requirement (15.58 million tonnes). The present consumption is only 44g/day/head against $220 \mathrm{~g}$ of Recommended Dietary Allowance (RDA). Though the area and production of brinjal (rabi) are found decreasing, its productivity is in increasing trend. This might be due to popularization of Integrated Pest Management (IPM) technology in controlling the most important insect like brinjal shoot and fruit borer. Cabbage, cauliflower, tomato and potato are found to have slow incremental growth rate in respect of area, production and productivity.

Production and productivity of spice crops have a remarkable incremental growth rate which might be due to use of modern varieties and improved agrotechniques with high return (Table 4). Bangladesh is producing about 1.2 million tonnes of spices against annual demand of about 2.6 million tonnes (Hussain and Iqbal, 2011). Among the major spice crops, the area and production of onion and garlic are found to be increasing at different levels in the recent years but decreasing trend was noticed for chilli. So, major research thrust needs to be given in the areas of development of high yielding varieties and hybrids, cultivation in the homestead, hills, southern belts along with improved management practices. The crops with yield growth rate are summarized in Table 5.

It is observed from table 5 that cereal crop production does not cope with its requirement due to increased population. The population growth rate of Bangladesh is recorded about $1.38 \%$ compared to $1.34 \%$ in India, $0.86 \%$ in USA, $0.56 \%$ in Thailand, $0.70 \%$ in UK and $0.51 \%$ in China (World Bank, 2009). It is fact that, rice is staple food grain crop of Bangladeshi people followed by wheat. The cereal crop production was found deficit up to 1998-99 while it was found surplus in production during 2008-09 and the projected year 2020. This growth in production has been achieved through expansion of irrigation facilities, spread of modern varieties and increase in cropping intensity (Talukder, 2005). This trend of vertical growth is needed to be sustained in future to meet the food requirement and for self-sufficiency in food grain. Pulses, oilseeds and vegetables are found deficit in production as per requirement during 1978-79 to 2008-09 and also in the projected year 2020. Lack of high yielding and short duration varieties, inadequate irrigation, cultivation of inferior lands, improper fertilizer use, slow transfer of pest and diseases, slow transfer 
of technology etc. are major constraints of the production of pulses and oilseeds in Bangladesh. Though the production of vegetables is in increasing trend, its daily consumption is less than the requirement. So, in addition to increase the production of vegetables, initiatives to be taken to increase its consumption. Overall, emphasis may be given to grow more pulses, oilseeds and vegetables. Since pulses, oilseeds and vegetables are considered as the major sources of proteins, fats, vitamins and minerals; the production of these crops is needed to be increased with priority basis.

Table 5: Crops with productivity growth rate during 1999-00 to 2008-09

\begin{tabular}{l|l}
\hline \multicolumn{1}{c|}{ Productivity growth rate } & \multicolumn{1}{c}{ Crops } \\
\hline High productivity growth rate $(>5 \%)$ & $\begin{array}{l}\text { Maize, Mango, Pineapple, Cotton, Onion, } \\
\text { Garlic, Chilli }\end{array}$ \\
Slow productivity growth rate (0-5\%) & $\begin{array}{l}\text { Jackfruit, Cauliflower, Cabbage, Mung, Rape } \\
\text { \& Mustard, Potato, Lentil, Brinjal (Rabi), } \\
\text { Banana, Rice, Tobacco, Jute, Tomato, } \\
\text { Groundnut, Chickpea, Tea }\end{array}$ \\
Negative productivity growth rate & Wheat, Sugarcane \\
\hline
\end{tabular}

Table 6: Cereals, Pulses, Oilseeds and Vegetables requirement with Production Figures in Bangladesh

\begin{tabular}{|c|c|c|c|c|}
\hline Year & $\begin{array}{c}\text { Population estimates } \\
\text { (millions) }\end{array}$ & $\begin{array}{c}\text { Requirement (t in } \\
\text { '000) }\end{array}$ & $\begin{array}{c}\text { Production } \\
\text { (000't) }\end{array}$ & $\begin{array}{c}\text { Surplus/Deficit } \\
\text { (000't) }\end{array}$ \\
\hline Cereals & 71.0 & 11715 & 11612 & -103 \\
\hline $1978-79$ & 106.3 & 17541 & 14558 & -2983 \\
\hline $1988-89$ & 124.3 & 20518 & 19361 & -1157 \\
\hline $1998-99$ & 142.3 & 23482 & 30813 & 7331 \\
\hline $2008-09$ & 185.0 & 30527 & 37314 & 6787 \\
\hline $2020 *$ & 71.0 & 1164 & 218 & -946 \\
\hline Pulses & 106.3 & 1743 & 495 & -1248 \\
\hline $1978-79$ & 124.3 & 2039 & 499 & -1540 \\
\hline $1988-89$ & 142.3 & 2334 & 195 & -2139 \\
\hline $1998-99$ & 185.0 & 3034 & 593 & -2441 \\
\hline $2008-09$ & 71.0 & 2563 & 264 & -2299 \\
\hline $2020 *$ & \multicolumn{5}{|l|}{} \\
\hline Oilseeds & \multicolumn{5}{|l|}{} \\
\hline $1978-79$ & \multicolumn{5}{|l|}{} \\
\hline
\end{tabular}




\begin{tabular}{|c|c|c|c|c|}
\hline $1988-89$ & 106.3 & 3837 & 426 & -3411 \\
\hline $1998-99$ & 124.3 & 4489 & 475 & -4014 \\
\hline $2008-09$ & 142.3 & 5137 & 661 & -4476 \\
\hline $2020 *$ & 185.0 & 6679 & 1225 & -5454 \\
\hline Vegetables & 71.0 & 5183 & 752 & -4431 \\
\hline $1978-79$ & 106.3 & 7760 & 980 & -6780 \\
\hline $1988-89$ & 124.3 & 9077 & 1526 & -7551 \\
\hline $1998-99$ & 142.3 & 10389 & 3150 & -7239 \\
\hline $2008-09$ & 185.0 & 13506 & 3976 & -9530 \\
\hline $2020 *$ &
\end{tabular}

* Projected Source: BBS (2007, 2010)

Note: Cereals requirement is estimated based on major cereals (165 kg/year/person)

Pulses requirement is estimated based on $16.4 \mathrm{~kg} /$ year/person

Oilseeds requirement is estimated based on $36.1 \mathrm{~kg} / \mathrm{year} /$ person

Vegetables requirement is estimated based on $73 \mathrm{~kg} / \mathrm{year} /$ person

\section{Regional Perspective}

When comparing the cereal crop production with its requirement in division wise during the year 2008-09, it is observed that Chittagong, Barisal and Rangpur are deficit in production (Table 7). Pulses and oilseed crop production are found in deficit in all the divisions. Vegetable production was found deficit in all divisions except Khulna. Divisions deficit with cereals, pulses, oilseeds and vegetables should be emphasized more to fulfill the regional requirement with the use of appropriate cropping patterns with high yielding varieties and modern agro-techniques.

The net area sown in Bangladesh is about 7943.7 thousand hectares which accounts about $53.8 \%$ of the total area (Table 8). It is fact that there is very limited scope to increase the areas under net crop because of a remarkable portion (24.2\%) is not suitable for cultivation and about $1 \%$ of the total land area is declining every year due to increased demand for non-agricultural activities like housing, industrialization and infra-structure development (Action Aid, 2011). A large variation is observed in respect of net area sown in different divisions (646.15 to 1924.29 thousand hectares). Rajshahi, Dhaka, Khulna, Chittagong and Rangpur divisions have been found utilizing the lands more than once in a year. This might be due to adopting suitable cropping patterns in these divisions. Areas sown more than once have been observed the minimum in the Barisal and Sylhet divisions having also the lower cropping intensity of 158 and 148\% respectively. These might be due to some fallow lands having salinity in the Barisal and haor basin in the Sylhet division. Initiatives are needed to grow more than one crop in a year from a single unit of land using suitable 
cropping patterns in all the divisions with greater emphasis to the Barisal and Sylhet division. Development of short duration high yielding varieties of crops with irrigation infra-structure are the gateway for growing crops more than once in a year.

Table 7: Cereals, Pulses, Oilseeds and Vegetables requirement with Production figures in different divisions (2008-09)

\begin{tabular}{|l|c|c|c|c|}
\hline Division & $\begin{array}{c}\text { Population } \\
\text { (2008-09) } \\
\text { (million) }\end{array}$ & $\begin{array}{c}\text { Requirement** } \\
\text { (000't) }\end{array}$ & $\begin{array}{c}\text { Production*** } \\
\text { (000't) }\end{array}$ & $\begin{array}{c}\text { Surplus/Deficit } \\
\text { (000't) }\end{array}$ \\
\hline Cereals & \multicolumn{5}{|l|}{} \\
\hline Dhaka & 46.7 & 7710 & 7756 & 46 \\
\hline Chittagong & 28.0 & 4633 & 4203 & -430 \\
\hline Rajshahi & 18.3 & 3024 & 8192 & 5168 \\
\hline Khulna & 8.1 & 1344 & 4364 & 3020 \\
\hline Barisal & 15.5 & 2567 & 2064 & -503 \\
\hline Sylhet & 9.8 & 1618 & 2206 & 588 \\
\hline Rangpur & 15.6 & 2584 & 2024 & -560 \\
\hline Total & 142.0 & 23480 & 30809 & 7329 \\
\hline
\end{tabular}

Pulses

\begin{tabular}{|l|c|c|c|c|}
\hline Dhaka & 46.7 & 766 & 59 & -707 \\
\hline Chittagong & 28.0 & 460 & 17 & -443 \\
\hline Rajshahi & 18.3 & 300 & 29 & -271 \\
\hline Khulna & 8.1 & 133 & 59 & -74 \\
\hline Barisal & 15.5 & 255 & 26 & -229 \\
\hline Sylhet & 9.8 & 160 & 1 & -159 \\
\hline Rangpur & 15.6 & 256 & 3 & -253 \\
\hline Total & 142.0 & 2330 & 194 & -2136 \\
\hline
\end{tabular}

Oilseeds

\begin{tabular}{|l|c|c|c|c|}
\hline Dhaka & 46.7 & 1686 & 189 & -1497 \\
\hline Chittagong & 28.0 & 1013 & 131 & -882 \\
\hline Rajshahi & 18.3 & 661 & 123 & -538 \\
\hline
\end{tabular}




\begin{tabular}{|l|c|c|c|c|}
\hline Khulna & 8.1 & 294 & 137 & -157 \\
\hline Barisal & 15.5 & 561 & 51 & -510 \\
\hline Sylhet & 9.8 & 354 & 13 & -341 \\
\hline Rangpur & 15.6 & 565 & 15 & -550 \\
\hline Total & 142.0 & 5134 & 659 & -4475 \\
\hline
\end{tabular}

Vegetables

\begin{tabular}{|l|c|c|c|c|}
\hline Division & $\begin{array}{c}\text { Population } \\
\text { (2008-09) } \\
\text { (million) }\end{array}$ & $\begin{array}{c}\text { Requirement** } \\
\text { (000't) }\end{array}$ & $\begin{array}{c}\text { Production*** } \\
\text { (000't) }\end{array}$ & $\begin{array}{c}\text { Surplus/Deficit } \\
\text { (000't) }\end{array}$ \\
\hline Dhaka & 46.7 & 3411 & 889 & -2522 \\
\hline Chittagong & 28.0 & 2049 & 658 & -1391 \\
\hline Rajshahi & 18.3 & 1338 & 462 & -876 \\
\hline Khulna & 8.1 & 594 & 807 & 213 \\
\hline Barisal & 15.5 & 1136 & 89 & -1047 \\
\hline Sylhet & 9.8 & 715 & 97 & -618 \\
\hline Rangpur & 15.6 & 1143 & 145 & -998 \\
\hline Total & 142.0 & 9363 & 3147 & -6216 \\
\hline
\end{tabular}

* Population (Source : BBS)

** Requirement is estimated based on $165,16.4,36.1$ \& $73 \mathrm{~kg}$ of cereals, pulses, oilseeds \& vegetables per year per capita

*** Production year 2008-09 $\mathrm{t}=$ tonne 
Table 8: Division-Wise Cropping Intensity \& Cropping Pattern (2008-09)

\begin{tabular}{|c|c|c|c|c|l|c|}
\hline Division & $\begin{array}{c}\text { Area (000' } \\
\text { ha) }\end{array}$ & $\begin{array}{c}\text { Share as } \\
\text { \% of } \\
\text { total area }\end{array}$ & $\begin{array}{c}\text { Net area } \\
\text { sown } \\
\text { (000' ha) }\end{array}$ & $\begin{array}{c}\text { Area sown } \\
\text { more than } \\
\text { once } \\
\text { (000' ha) }\end{array}$ & \multicolumn{1}{|c|}{ Major Cropping Patterns } & $\begin{array}{c}\text { Cropping } \\
\text { intensity } \\
\text { (\%) }\end{array}$ \\
\hline Dhaka & 3111.9 & 21 & 1924.29 & 2860.32 & $\begin{array}{l}\text { Boro rice-Fallow-T. Aman rice } \\
\text { Mustard- Boro rice-T. Aman rice }\end{array}$ & 184.16 \\
\hline Chittagong & 3377.1 & 23 & 1070.85 & 1546.96 & $\begin{array}{l}\text { Winter vegetables-Fallow- T. } \\
\text { Aman rice } \\
\text { Boro rice-Fallow-T. Aman rice }\end{array}$ & 169.33 \\
\hline Rajshahi & 1819.6 & 12 & 1812.55 & 3105.27 & $\begin{array}{l}\text { Boro rice-Fallow-T. Aman rice } \\
\text { Wheat-Mungbean-T. Aman rice }\end{array}$ & 201.25 \\
\hline Khulna & 2227.4 & 16 & 1102.02 & 1644.53 & $\begin{array}{l}\text { Boro rice-Fallow-T. Aman rice } \\
\text { Wheat-Jute/B.Aus rice -T. Aman } \\
\text { rice }\end{array}$ & 190.33 \\
\hline Barisal & 1329.7 & 9 & 768.42 & 830.79 & $\begin{array}{l}\text { Fallow-T. Aus rice-T. Aman rice } \\
\text { Fallow-Fallow-T. Aman rice }\end{array}$ & 158.00 \\
\hline Sylhet & 1259.6 & 8 & 646.15 & 569.23 & $\begin{array}{l}\text { Fallow-T. Aus rice-T. Aman rice } \\
\text { Boro rice-Fallow-Fallow }\end{array}$ & 148.00 \\
\hline Rangpur & 1631.7 & 11 & 619.43 & 1114.17 & $\begin{array}{l}\text { Potato- Boro rice-T.Aman rice } \\
\text { Fallow- Boro rice-T.Aman rice }\end{array}$ & 199.00 \\
\hline Bangladesh & 14757.0 & 100 & 7943.71 & 11671.27 & & 182.00 \\
\hline
\end{tabular}

\section{Export-Import of Agricultural Crops:}

An adverse trade balance is observed between exports and imports during 2001-02 to 2008-09 (Table 9). Terms of trade has been found to be in favour of imports causing a lot of burden on foreign exchange. It is now high time that production of the agricultural crops must be given priority to reduce the improper trade balance.

\section{Value of products:}

The value of products are estimated as per production and market price of 2008-09 (Table 10). From the table, it is revealed that rice, jute, potato, chilli, oilseeds, sugarcane and wheat contribute about 51.4\%, 14.9\%, 9.9\%, 6.6\%, 2.7\%, $1.4 \%$ and $1.4 \%$ of total value respectively. So, steps to be taken to increase the production of these crops to get maximum return and to reduce the import. 
Table 9: Year-Wise Export/Import of Agricultural Crops

\begin{tabular}{|c|c|c|c|}
\hline Year & $\begin{array}{c}\text { Total exports } \\
\text { (Million Tk.) }\end{array}$ & $\begin{array}{c}\text { Total imports } \\
\text { (Million Tk.) }\end{array}$ & $\begin{array}{c}\text { Terms of Trade } \\
\text { (Export/import) }\end{array}$ \\
\hline $2001-02$ & 5386 & 41010 & 0.13 \\
\hline $2002-03$ & 6437 & 57091 & 0.11 \\
\hline $2003-04$ & 7087 & 18641 & 0.38 \\
\hline $2004-05$ & 9556 & 75397 & 0.13 \\
\hline $2005-06$ & 12977 & 105729 & 0.12 \\
\hline $2006-07$ & 14586 & 58344 & 0.25 \\
\hline $2007-08$ & 22202 & 74006 & 0.30 \\
\hline $2008-09$ & 37281 & 90929 & 0.41 \\
\hline
\end{tabular}

Source: BBS (2010)

Note: The exportable crops include jute, vegetable and tea

The importable crops include oilseeds, pulses, onion, ginger and sugar

Table 10: Value of Products (2008-09)

\begin{tabular}{|l|c|c|c|}
\hline Crops & $\begin{array}{c}\text { Production } \\
\text { (000'tonnes) }\end{array}$ & $\begin{array}{c}\text { Total value } \\
\text { (Tk. in billion) }\end{array}$ & $\begin{array}{c}\text { \% share of } \\
\text { total value }\end{array}$ \\
\hline Rice & 27591 & 393.4 & 51.4 \\
\hline Wheat & 736 & 10.6 & 1.4 \\
\hline Maize & 729 & 6.9 & 0.9 \\
\hline Jute & 4677 & 114.6 & 14.9 \\
\hline Sugarcane & 5232 & 10.9 & 1.4 \\
\hline Potato & 5268 & 76.0 & 9.9 \\
\hline Lentil & 60 & 3.6 & 0.5 \\
\hline Khesari & 75 & 2.1 & 0.4 \\
\hline Onion & 154 & 3.7 & 0.5 \\
\hline Garlic & 72 & 1.8 & 0.3 \\
\hline Ginger & 88 & 4.0 & 6.6 \\
\hline Chilli & 735 & 51.2 & 2.7 \\
\hline Oilseeds & 601 & 20.7 & 8.6 \\
\hline Mustard) & 3284 & 65.6 & 100.0 \\
\hline Others & 49309 & 765.1 & \\
\hline Total & & & \\
\hline
\end{tabular}




\section{Research allocation:}

Share of research allocation to NARS institutes as percentage of Annual Development Programme (ADP) is found to be increasing during 2004-05 to 2008-09 (Table 11). On the other hand, share of research allocation as percentage of Gross Domestic Product (GDP) has remained more or less static (0.05 to $0.06 \%)$. It is reported that the research and development budget as percentage of GDP in USA is $2.82 \%$, India is $0.80 \%$ and Pakistan is $0.67 \%$ (World Bank, 2011). There is now evidence that the external support for research and development is declining and at the same time developing countries are also providing less support to agricultural $\mathrm{R}$ \&D. Dey and Deb (1990) also reported that government continues to under invest in agricultural research and that scope remains for the government to invest more.

Table 9: Research Allocation to NARS Institutes

\begin{tabular}{|l|c|c|c|c|c|}
\hline Year & $\begin{array}{c}\text { GDP at } \\
\text { constant } \\
\text { market price } \\
\text { (Base year: } \\
\begin{array}{c}\text { 1995-96) } \\
\text { (In Lakh Tk.) }\end{array}\end{array}$ & $\begin{array}{c}\text { Research* } \\
\text { Expenditure } \\
\text { (In Lakh Tk.) }\end{array}$ & $\begin{array}{c}\text { ADP } \\
\text { Expenditure } \\
\text { (Country } \\
\text { Allocation) } \\
\text { (In Lakh Tk.) }\end{array}$ & $\begin{array}{c}\text { Share of } \\
\text { Research } \\
\text { Allocation as \% } \\
\text { of ADP }\end{array}$ & $\begin{array}{c}\text { Share of } \\
\text { Research } \\
\text { Allocation as \% } \\
\text { of GDP }\end{array}$ \\
\hline $2004-05$ & 37070700 & 16817.11 & 187710 & 9.48 & 0.05 \\
\hline $2005-06$ & 41615500 & 23271.00 & 194730 & 12.56 & 0.06 \\
\hline $2006-07$ & 47247700 & 26057.14 & 179170 & 15.28 & 0.06 \\
\hline $2007-08$ & 54582200 & 25683.79 & 184500 & 14.73 & 0.05 \\
\hline $2008-09$ & 61479500 & 29618.18 & 197000 & 15.85 & 0.05 \\
\hline
\end{tabular}

* Excluding research cost for livestock \& fisheries

Source: Bangladesh economic Review-2010 and Bangladesh Agricultural Research Council (BARC)

\section{CONCLUSIONS AND RECOMMENDATIONS}

Based on the analyses of growth rate of area, production and yield of different crops, land use pattern, gross domestic product, regional contribution to total production, exports and imports, research allocation, price of commodities etc, the following conclusions and recommendations are made:

1. Share of agriculture in GDP is $20.6 \%$ and the expenditure of agricultural research is only $0.05 \%$ of GDP which needs to be increased sharply for sustainable high growth in agriculture.

2. Bangladesh has seen the reduction in the growth rate of area under almost all crop groups i.e. cereals, cash crops, pulses, oilseeds, fruits and vegetables. But the productivity increase in these crop groups indicates an effective research and extension system. Increased investment in research systems will boost the overall vertical growth. 
3. Commodity wise rice is a dominating cereal crop and staple food of Bangladesh. Its negative growth in area is a matter of concern. There is also a vast yield gap in this crop. Rice research needs to be strengthened. Accordingly, the research fund in crop sector should be diverted to rice. However, precise allocation can be made based on the human resources involved in rice research in Bangladesh.

4. The promising growth rates in the yields of oilseed and pulses, and their demand for domestic consumption, it is necessitated to allocate high research funds for these crops.

5. Fruits and vegetables are dual purpose crops which have high nutritive value and cash earnings. The high productivity of these crops need to be harnessed through effective research.

6. Cash crops and spices give economic impetus to the farmers. The allocations need to be increased to sustain the growth of these crops.

7. Necessary steps to be taken to reduce import and increase export to minimize the adverse trade balance.

8. Dhaka, Chittagong, Barisal and Rangpur divisions are to be emphasized for increasing food grain production, and all divisions for pulses, oilseeds and vegetable production.

9. Maximum net area sown is in Dhaka division followed by Rajshahi, Khulna, Chittagong, Rangpur, Barisal and Sylhet. Therefore, research and development allocation can be done on this basis.

Overall, it may be concluded that the resource allocation to agricultural research needs to be increased to a considerable extent and its distribution to be made based on commodity and regional importance.

\section{REFERENCES}

Action Aid. 2011. The World Food Day-2011. Action Aid Bangladesh.

Bangladesh Economic Review. 2010. Finance Division, Ministry of Finance, Government of the People's Republic of Bangladesh, Dhaka.

BBS, 2007. Bangladesh Bureau of Statistics, Statistics Division, Ministry of Planning, Government of the People's Republic of Bangladesh, Dhaka.

BBS, 2010. Statistical Yearbook of Bangladesh. 2009. Bangladesh Bureau of Statistics, Statistics Division, Ministry of Planning, Government of the People's Republic of Bangladesh, Dhaka.

Bhuyan, M.A.J. and Hossain, M. A. 2009. Research and Development activities of BARI: An Overview. The Guardian, June 2009. pp. 79-85.

Contant, R. B. 2001. Priority setting. In Planning agricultural research (G. Gijbers, W. Janssen, H.H.Odame and G. Meijerink, eds.). CAB International, Wallingford, U. K. and ISNAR, The Hague, Neterlands. 
Dey, M. M. and Deb, U. K. 1990. The Economics of Investment in Agricultural Research in Bangladesh. Bangladesh Journal of Agricultural Economics, 13 (1-2):1-23.

Dey, M. M. and Norton, G. W. 1992. Rice Research Priorities in Bangladesh: A Quantitative Analysis. Bangladesh Journal of Agricultural Economics, 15 (2):1-17.

Hussain, S. G. and Iqbal, A. 2011. Research Priorities in Bangladesh Agriculture. Bangladesh Agricultural Research Council, Farmgate, Dhaka.

Jha, D.; Kumar, P.; Mruthyunjaya; Pal, S.; Selvarajan, S. and Singh, A. 1995. Research Priorities in Indian Agriculture. National Centre for Agricultural Economics and Policy Research (NCAP), New Delhi. Policy Paper No. 3.

Krishiworld. 2011. The Pulse of Indian Agriculture. www.krishiworld.com. Accessed on December 2011.

Pun, H.L. and Koala, S. 1994. Priority Setting in Agricultural Research: a comparison of different types of networks. Environment and Natural Resources Division, IDRC, Ottawa- Canada.

Paper presented at the Roundtable Discussion on Setting Regional Priorities for Agricultural Research. Le Hague-Netherlands. April 18-20, 1994.

Talukder, R. K. 2005. Food Security, Self-sufficiency and Nutritional Gap in Bnagladesh. The Bangladesh Development Studies, 31(3-4):35-62.

World Bank. 2009. Population Growth (annual \%). The World Bank Group. data.worldbank.org.

World Bank. 2011. Research and Development Expenditure (\% of GDP). The World Bank Group. data.worldbank.org. 